\title{
〔77 78〕塩化ビニルの重合に関する研究
}

第 1 報 重合禁止期間における酸素の挙動

(1957 年 10 月 16日受理)

平思稔* 前本権 一*

要 旨塩化ビニルを過酸化水秦の存在において乳化重合せしめようとするとき, 反応系内に酸素が共存すると, 塩 化ビニル単独の重合に先立って，まず，塩化ビニルと酸素とよりなる化合物を生ずる。この化合物を反応系より分離し，これが 一般式 $[-m \mathrm{VC}-\mathrm{O} \cdot \mathrm{O}-]_{n}$ で表わされることを知った。 $m$ の值はほとんど 1 に近く，nは 4 より大きいが割合に小さい值であ ると推定される。

\section{1. 緒言}

不飽和化合物の重合において酸素が単量体化合物の種類および重合条件により, 重合に対して, 禁止的に あるいは促進的に影短を与えることはよく知られている。

古くH. Staudinger は unsym. diphenylethyleneと酸素が moloxide 型のものを経て diphenyl ethylene peroxide を生成し1)，またスチレンについても酸素の含まれたポリスチレンが得られることを述べている゙2。

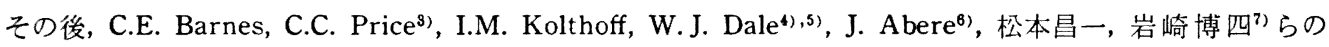
重合反応における酸素についての報告がある。しかしながら, F.A. Bovey, I.M. Kolthoff ${ }^{8), 9)}$, C.E. Barnes, R.M. Elofson, G.D. Jones ${ }^{10)}$, K.C. Smeltz, E. Dyer ${ }^{11)}$ らのメチルメタアクリレート, スチレン, アクリロ ニトリルなどと酸素に関する報告は最も代表的でありその本質に触れていると思われる。彼らによれば, 酸 素はこれらの不飽和化合物と作用して重合度 3〜100 程度の polymeric peroxide を生成し, この peroxide は単量体化合物の種類およびそのときの条件によって安定であるか, あるいは不安定でラジカル的に分解す るかによって重合が禁止され，または促進されるという。

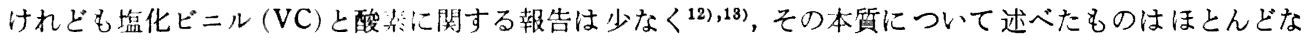
い。著者らはVCについて触媒として過酸化水素, 調整剤として第二リン酸ソーダ, 乳化剤として di-alkylsodiumsulfosuccinate (ASS) を用いた乳化重合系においても酸素に起因する重合禁止期間を認め, この時期 における酸素の挙動について研究を行い, polymeric peroxide の生成を確認できたと思われるので, ここに 報告する。

\section{2. 実験}

過酸化水素, 第二リン酸ソーダ, ASS $0.10 \%$ を含む水性液 $18 \mathrm{cc}$ と VC $6 \mathrm{~g}$ を冷凍状態で内容 $70 \mathrm{cc}$ の耐 圧ガラス管に空気相とともに熔封した後, $45^{\circ} \mathrm{C}$ の恒温槽中で封管の長さに直角な方向を軸として回転力キマ ゼし，4〜24 時間反応を行わしめた。その後封管を開きVC を気化せしめると, 後に微量の白色粘稠の浮遊 物が認められた。上記のガラス封管 16 本を 1 組として同時に同一条件で実験を行い, 開封後は全反応物を集 め観察した。

\footnotetext{
* 住友化学工業株式会社新居浜製造所研究部 (新居捠市乙 31)
} 


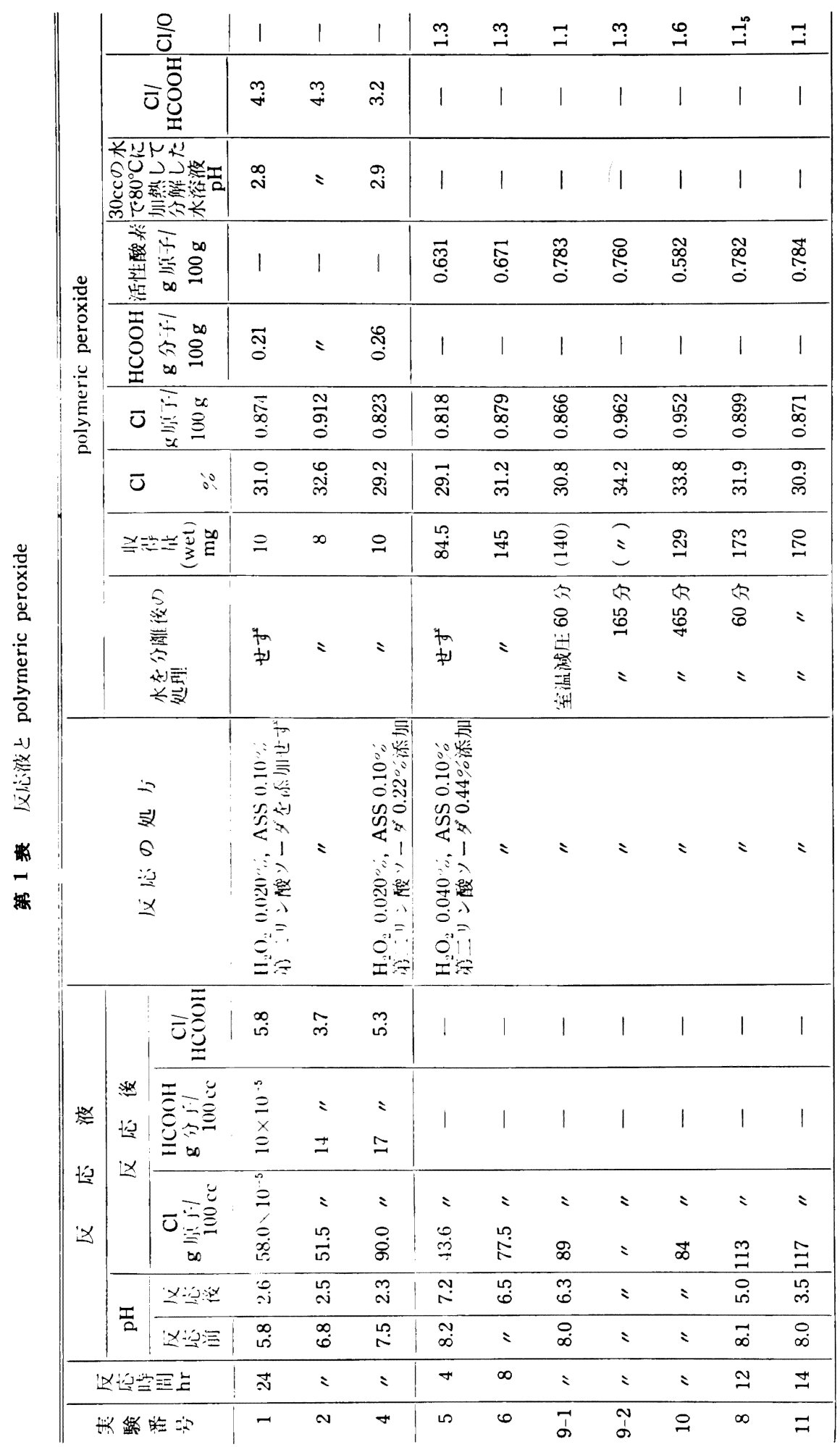


なお，ガラス管内に過酸化水素を添加しないときに酸素が存在している場合，または過酸化水素を添加し ても酸素が存在しない場合はいずれも前記の反応条件を与えても白色浮游物の生成は認められず，また反応 液の $\mathrm{pH}$ の低下もなかった。

1）反応液 反応生成物より浮游物を除いた反応液について調べてみた。この溶液の $\mathrm{pH}$ は応開始時 に比して著しく低下していた。第 1 表にその結果を示す。

a) ホルムアルデヒドの確認 反応液に 2,4-dinitro phenylhydrazine の $10 \%$ 硫酸飽和液を加えると 黄色の沈殿が得られる。これをロ別水洗し低温で乾燥したものを顕微鏡下に融点を観測すると $125 \sim 150^{\circ} \mathrm{C}$ で,これを昇華精製して同様に融点測定を行えば, 160 〜 $162^{\circ} \mathrm{C}$ であった。別に市販のホルマリンより同様の 操作で得られた formaldehyde-2,4-dinitrophenylhydrazone もやはり $160 \sim 162^{\circ} \mathrm{C}$ でささらにこれを上記 精製試料と混融を行っても融点の低下は恋められない。したがって反応液より得られた黄色沈殿は formaldehyde-2, 4-dinitrophenylhydrazone であり, 反応液中に明らかにホルムアルデヒドの生成を確認すること ができる。

文献“)による同物質の融点は $156^{\circ} \mathrm{C}$ であるが，本実験による值との差異は測定装置の相違によるものと思 われる。

b) ギ酸の確認 ギ酸水溶液に塩化第二水銀の飽和水溶液を加えて加熱するときは, 塩化第一水銀と

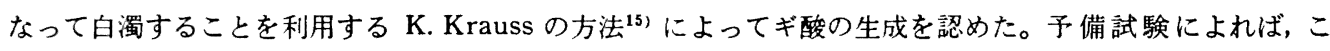
の方法で濃度 $0.01 \mathrm{mg} / \mathrm{cc}$ 以上の場合にギ酸の存在を確認できる。精密に定量することはできないが既知濃 度の試料と，沈殿生成の速度や状態を比較することによって，およそのギ酸存在量を知ることができる。

c）塩素の定量 反応液中にイオン性の塩素の存在が認められるので, 十分の $N / 10$ 硝酸銀溶液を加え て塩素と反応せしめ，過剩の硝酸銀を鉄アンモニウムミョウバンの飽和溶液を指示薬として $N / 10$ ロダンア ンモン溶液で滴定を行い, 塩素量を求めた。

反応液中に共存するギ酸濃度は低く塩素の定量を妨げない。VCそのものは硝酸銀によって塩化銀を沈殿 しないことがよく知られているので,ここに硝酸銀によって沈殿する塩素は, 硝酸銀の添加以前にすでにイオ ン性の塩素として水溶液中に存在するものである。

反応液中のリン酸根の影餙は硝酸銀の添加を，やや強い酸性の下で行うことによって避けることができた。

2) 白色の浮遊物 反応生成物の上面に見られる白色の浮遊物を集め，口紙上で脱水し，あるいはさら に減圧下に室温で乾操燥作を行ったものについて分析を行った。

これは後に記すように非常に不女定で，分解を起すことなく簃密な乾燥を行うことができなかった。

a) polymeric peroxide の生成 反忘を行わしめた後, 耐圧がラス管を開いて, VC を気化せしめてか ら粘稠な浮遊物を集めようとすると、しだいにわずかに灰色を帯びてくる。分解が起っているものと思われ る。浮遊物を集めてロ紙で水分を除けばガラス封管 1 本につき通常約 $10 \mathrm{mg}$ のチ状物質が得られる。これ はメタノールに不溶でニトロ ゙ンゼンに溶解し，その溶液は漸次黒くなる。この傾向は約 $50^{\circ} \mathrm{C} に$ 加熱する と著しい。テトラハイドロフランにも溶解するが, その溶液に水銀, 鉛などの金属が触れると発泡とともに 異様な臭気を発して瞬間的に分解する。ベンゼン, 四塩化炭素の順にその溶解度は小さくなる様子で二硫化 炭素には溶解しない。これらの溶液にメタノールを加えると白色沈殿がわずかに析出するが, 再沈殿法によ る精製法として採用することはむずかしい。またこのモチ状物質を直接バーナー上で加熱すると激しい音を 伴って爆発し，わずかな衝撃によっても爆発することがある。ヨウ化カリの水酶酸溶液よりヨウドを遊離せ 
しめ, 自らはしだいに溶解する。

b) polymeric peroxide の赤外線吸収 次にこのモチ状物質の構造について検討するために赤外線吸収 を見た。第 1 表中の実験番号 6 と同じ応処 方によって得られたもチ状物を氷冷しながら 90〜120 分間減圧下に乾嬠したものについて 得た赤外線吸収の結果を 1 例として第 1 図に 示す。

この試料は $(-\mathrm{VC}-\mathrm{O} \cdot \mathrm{O}-)_{\boldsymbol{n}}$ として活性酸 素量よりその純度を求めると $71.2^{\circ} \circ$ ○゙あっ た。図中強い $2.9 \mu$ の吸収は $\nu(\mathrm{O}-\mathrm{H})$ である が, 水による他の吸収带 $6.1 \mu$ は影著には認

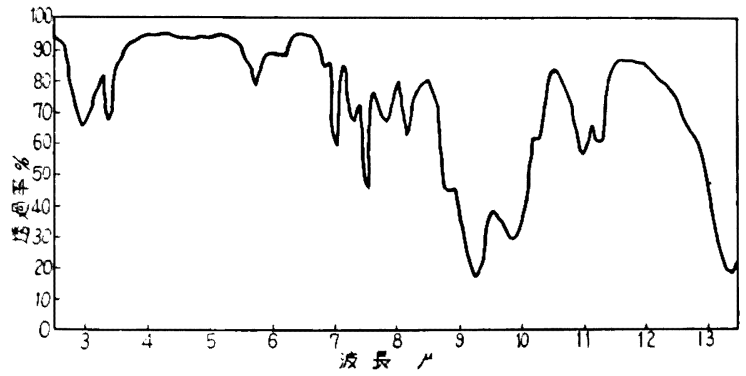

第 1 図 polymeric peroxide の赤外楾吸収 められないので $2.9 \mu$ は水によるものではない。また $3.4 〜 6.3 \mu$ の吸収は試料ごとにその相対強度が変化す るので，不純物かあるいは分解生成物による吸収であると考えられるが，7.0〜13.4 $\mu$ はそのような相対強度

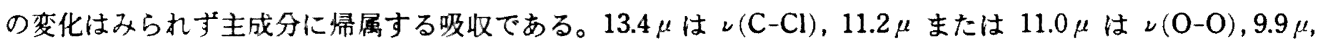

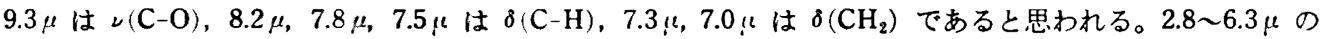
間の吸収については不純物による可能性が考えられるが, 次項に示した分解生成物である塩酸は $3.5 \mu, 3.6 \mu$, ギ酸は $3.3 !$ ! $8.2 \mu, 5.7 !$ ，ホルマリンは $5.7 ! 、 6.1 \mu, 10.5 !$ にそれぞれ強い吸収を持つが，第 1 図に見られ る吸収曲線はこれらがいずれも問題になる程度には存在していないことを示している。この結果より試料化 合物は $\left[-m\left(\mathrm{CH}_{2}-\mathrm{CHCl}\right)-\mathrm{O} \cdot \mathrm{O}-\right]_{n}$ かあるいは $\mathrm{O}-\mathrm{CH}_{2}-\mathrm{CHCl}-\mathrm{O}^{16)}$ などの比較的簡単な構造を有する物質 であると考えられる。

c) polymeric peroxide の分子量 またこの試料についてニトロベンゼンに用いて氷点降下法により 分子量を求めると分子量 374 を得た。用いた試料は完全に精製，乾燥し得たものではないから，少量の低分 子不純物が 存在していることは当然考えられるので，分解を起す以前にはこの化合物はこの值より高い分子 量をもっていたものと考えられる。

さらに同時に調製した試料化合物の $1.53 \mathrm{~g} / l, 0.77 \mathrm{~g} / l$ のニトロベンゼン溶液について粘度法により分子量 測定を行い, VC 単独重合物に用いられる枚田 ${ }^{17}$, 松本 ${ }^{18)}$ 両氏の計算式を用いて平均分子量を求め, それぞれ 406, 437 を得た。この值には種々問題があるけれども前記の水点降下法による分子量とだいたいその大きさ は一致している。- $\mathrm{CH}_{2}-\mathrm{CHCl}-\mathrm{O} \cdot \mathrm{O}$ 一の分子量は 94.5 であるので, 以上のことより白色の粘稠な浮遊物は 低重合度の polymeric peroxide であると考えられる。

d) polymeric peroxide の反応 前述のよらにして得られた白色の化合物 polymeric peroxide の反応

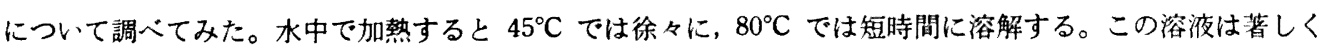
$\mathrm{pH}$ が低く，また前項に記した分析法によってホルムアルテヒド, キ酸, イオン性塩素を確認することがで きる。

polymeric peroxide 中の活性酸素量は polymeric peroxide をヨウ化カリの水酢酸溶液に作用させて遊離 したヨウドを $N / 10$ チオ硫酸ソーダ夜で滴定して求めた。

第 1 表に見られる值は白色浮遊物の polymeric peroxide を $30 \mathrm{cc}$ の水によって $80^{\circ} \mathrm{C}$ に加熱して分解し て得た液について試験した結果である。 


\section{3. 実験結果の考察}

乳化剈水溶液中の VC を酸素と共存せしめても変化が認められないが，これに過酸化水素を添加して置く とpolymeric peroxideを生ずることを述べた。第 1 表および 第 2 図に見られるようにこの polymeric peroxide は反応時 間とともに増加し，また添加した過酸化水素の量が多い方が 多い。しかしながら反応時間がある程度以上になると poly・ meric peroxide の分解による減少と分解のために起る $\mathrm{pH}$ の低下に基因する polymeric peroxide の生成速度の減少に よって polymeric peroxide の実在量はかえって少なく なる。

polymeric peroxide の分解によって確認されるイオン性 の塩素の量の割合はいずれも30\%程度でほとんど一定して いるつに反して, ギ酸, 活性酸素の量の割合には相当の差異が ある。特に活性酸素については実験番号 9-1, 8,11に見られ るように, 反応後の乾燥処理が同様ならば反応時間の相違に よっても $\mathrm{Cl} / \mathrm{O}$ の比はほとんど変化がないが, 実験番号 9-1, 9-2,10に見られるように減圧乾燥処理の時間が長くなれば, 第3図に示すよ5に $\mathrm{Cl} / \mathrm{O}$ の比はしだいに大きい值を示すよ うになる。塩素の含有割合はほとんど変らないので $\mathrm{Cl} / \mathrm{O}$ が 大きくなることは，すなわち乾燥処理によってしだいに活性 酸素が失われて行くことを示している。実験番号 $1,2,4$ にお 心て, 反応液上 polymeric peroxide 分解液の中にはいずれ 己塩素とギ酸を認め, その比 $\mathrm{Cl} / \mathrm{HCOOH}$ は 3 6 6間にあ り, 反応液中に反応開始時にはイオン性の塩素もギ酸も存在 しないことは明らかであるからこれらはいずれも反応の進行

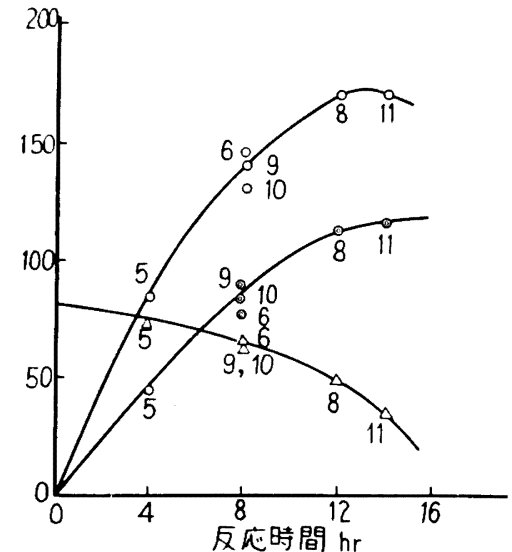

: peroxide の收得量 $(\mathrm{mg})$

：反応後の反応液中の $\mathrm{Cl}$ 量 $\left(\times 10^{-5}\right.$ $\mathrm{g}$ 原子/ $100 \mathrm{cc}$ )

$\triangle$ : 反応後の反応液の $\mathrm{pH}\left(\times 10^{-1}\right)$ 図中の数字は実験番号を示す

第 2 図 反応時間の影響

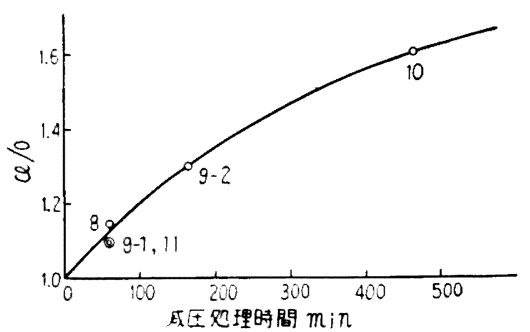

図中の数字は実験番号を示す

第 3 図 polymeric peroxide 中の $\mathrm{Cl} / \mathrm{O}$ と減圧処理時間 Łともに生ずる polymeric peroxide の分解によって生ずるもの上考えることができる。このことは実験番 号 5〜11において第2网に見られるように, 反応処方が同様ならば反応時間の長さとともに反笖淮中の塩素 濃度己，polymeric peroxide の収得量も増加することより明らかであり，また反応液中の $\mathrm{pH} か ゙$ 明らかに 低下するのは主としてこの polymeric peroxide の分解によって生ずる塩素(塩酸として)，ギ酸によるもの と考えることによっても首肯される。すなわち, 以上のことより polymeric peroxide は次のごとくして生 ずるものと思われる。*印はラジカルを示す。

$$
\begin{aligned}
& \mathrm{H}_{2} \mathrm{O}_{2} \longrightarrow 2 \mathrm{OH}^{*} \\
& \mathrm{OH}^{*}+\mathrm{VC} \longrightarrow \mathrm{HO}-\mathrm{VC}^{*}
\end{aligned}
$$

个2)式に示されるラジカルが、いくつかの VC またはその他のものと結合して生ずる一端に VCを持つ ラジカルを一般に〜VC*で表わすこととすれば,これは過酸化水素の共存の下に酸素と次のように反応 する。 


$$
\sim \mathrm{VC} *+\mathrm{O}_{2} \longrightarrow \sim \mathrm{VC}-\mathrm{O} \cdot \mathrm{O}^{*}
$$

この反応の進行は, 分子状酸素の存在のみでは起らず, 過酸化水素が共存しなけれ認められなかったの で一般にラジカル生成物質の共存を必要とするものであろう。

一方 VC と反応して

$$
\sim \mathrm{VC}^{*}+\mathrm{VC} \longrightarrow \sim \mathrm{VC}-\mathrm{VC} *
$$

の反応は第 1 表において示されているように polymeric peroxide の分解によって認められる塩素上,活性酸 素の量的割合が原子比において1に近い値をもっていることより，少なくとも重合系のこの過程においては (4)式の反応速度は(3)式の反応速度に比してはなはだ小さく, $m \fallingdotseq 1$ になってしまうと考える方が適当である。 さらに〜 VC-O.O* の反応については

$$
\begin{aligned}
& \sim \mathrm{VC}-\mathrm{O} \cdot \mathrm{O}^{*}+\mathrm{VC} \longrightarrow \sim \mathrm{VC}-\mathrm{O} \cdot \mathrm{O}-\mathrm{VC}^{*}=\sim \mathrm{VC}^{*} \\
& \sim \mathrm{VC}-\mathrm{O} \cdot \mathrm{O}^{*}+\mathrm{O}_{2} \longrightarrow \sim \mathrm{O} \cdot \mathrm{O}-\mathrm{O} \cdot \mathrm{O}^{*}
\end{aligned}
$$

の中, (6)式の反応は常識的にほ上んど考えられず, 連鎖の停止反応以外は主として(5)式の反応が起るである 5。したがって VC が酸素の共存の下に前記の反応条件に扔かれたときに起る反応在要約すれば

$$
m n \mathrm{VC}+n \mathrm{O}_{2} \longrightarrow(-m \mathrm{VC}-\mathrm{O} \cdot \mathrm{O}-)_{n}
$$

となり,この polymeric peroxide の末端基は強い赤外湶吸収が $2.9 \mu$ にあり, しかも $6.1 \mu$ にきわめて弱 いるのしか認められないことより $\mathrm{OH}$ 基であると考えられる。このことは polymeric peroxide の重合開 始および停止の機構から考えても可能性が大きい。第 1 表の polymeric peroxide に見られるように $\mathrm{Cl} / \mathrm{O}$ は 1 に近い数であり，特に polymeric peroxide の処理時間の短いものは 1.1 程度であることより，mの值は 1より大きいが 1 にはなは汒近いものであり，主として次式に近い形で反応すると考えた方がよい。

$$
n \mathrm{VC}+n \mathrm{O}_{2} \longrightarrow(-\mathrm{VC}-\mathrm{O} \cdot \mathrm{O}-)_{n}
$$

この polymeric peroxide は水と加熱すると(9)式によって分解する。 $\mathrm{VC}$ を $\mathrm{CH}_{2}=\mathrm{CHCl}$ と書き直せば,

$$
\left[-\mathrm{CH}_{2}-\mathrm{CHCl}-\mathrm{O} \cdot \mathrm{O}-\right]_{n}+n \mathrm{H}_{2} \mathrm{O} \longrightarrow n \mathrm{HCl}+n \mathrm{HCHO}+n \mathrm{HCOOH}
$$

このとき過酸化水素や polymeric peroxide が共存す机ば, その活性酸素によってホルムアルデヒドやギ

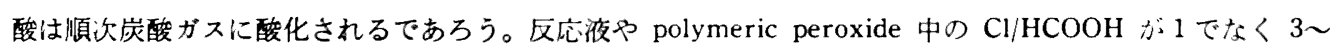
6 の值を示すのは，主としてこの酸化によるものと思われる。

また, polymeric peroxide の乾燥時間によって $\mathrm{Cl} / \mathrm{O}$ の值に差異を生ずるのは, polymeric peroxide 中 の連続した $2 つ の$ 酸素の多くの組の中, いくつかの組からそれぞれその 1 原子の酸素が放出されるためであ り, 活性を示すのも 2 つの中の 1 つの酸素である。この酸素の放出のときに polymeric peroxide がその部 分から切断されるかいなかについては確かめられなかったが, polymer がしだいに粘稠さを增すことよりあ まり切断は起らないと想像される。またこのときの塩化水素の放出も第 1 表の結果からきわめて少ないこと が知られる。

ここに $(-m \mathrm{VC}-\mathrm{O} \cdot \mathrm{O}-)_{n}$ または $(-\mathrm{VC}-\mathrm{O} \cdot \mathrm{O}-)_{n}$ の重台度, すなわち $n$ の值については先に重合物の分子 量として 374 を得ているが，用いられた試料の分解による純度の低下を考虑するとき 4 より大きい值である と思われるが，種々の性質よりして割合に小さいものであろう。

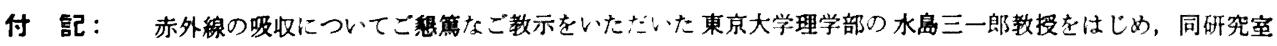
の方々および本報告の発表を触可せられた住友化学工業株式会社の上司の方々と赤外線吸收実験についてご劦かいただいた 同社松島俊輔理学士に感期の意を表します。 


\section{文献}

1) H. Staudinger: Ber., 58, 1075(1925)

2) H. Staudinger und L. Lautenschläger: Ann., 488, 1(1931)

3) C. E. Barnes: J. Am. Chem. Soc., 67, 217 (1945)

4) C. C. Price and C. E. Adams: J. Am. Chem. Soc., 67, 1674(1945)

5) I. M. Kolthoff and W. J. Dale: J. Am. Chem. Soc., 69, 441(1947)

6) J. Abere, H. Mark and W. P. Hohenstein : J. Appl. Chem., 1, 363(1951)

7) 本昌一, 岩崎博四：高化, 71, 402(1950)

8) F. A. Bovey, I. M. Kolthoff: J. Am. Chem. Soc., 69, 2143(1947)

9) F. A. Bovey, I. M. Kolthoff : Chem. Rev., 42, 491 (1948)

10) C. E. Barnes, R. M. Elofson and G. D. Jones: J. Am. Chem. Soc., 72, 210(1950)

11 K. C. Smeltz, E. Dyer: J. Am. Chem. Soc., 74, 623(1952)

12) Jean Prat: C. A., 42, 4392g(1948)

13) K. S. Minsker, A. S. Shevlyakov and G. A. Raznvaev: R. R. P., 10, 11, 971(1956)

14) Beilsteins Handbuch : Der Organischen Chemie, 15, 490(1910)

15) K. Krauss: Ber., 62, 487 (1929)

16) 水谷久一, 相川隆太郎, 森沢保：工化, 55, 772(1952)

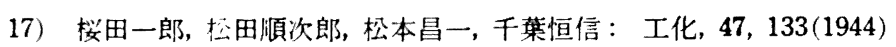

18) 松本昌一：工化, 52, 110(1949)

\section{Studies on Vinylchloride Polymerization}

\section{Behaviour of Oxygen in the Induction Period}

\section{By Minoru Hirata and Kenichi Maemoto}

In vinylchloride emulsion polymerization by hydrogen peroxide, if oxygen exists in reaction system, a copolymer of vinylchloride and oxygen is formed before vinylchlorid homopolymer. It appears that this copolymer has the general formula, $[-m \mathrm{VC}-\mathrm{O} \cdot \mathrm{O}-]_{n}$, in which the value of $m$ approximates to 1 and $n$ is larger than 4 but not so much. And it is most probable that the copolymer has $\mathrm{OH}$-groups at the ends.

\section{第 2 報雨合什此期湖と厔合速度に対する酸素の影響}

(1957年 10 月 16 日受理)

平田稳* 前优権一*白山侹 二**

要旨塩化ピニルの乳化重合采に酸素が存在するときは，塩化ピニルと酸秦よりなる polymeric peroxide を生成 し、さらにその分解こよって polymeric peroxide の量こ応じた pH の低下が起る。pHの低下は vinylchloride の単独 重台が始まるころから止まり、重台、本期から再び下る傾向がみられる。当初存在する酸素の最が多ければ重合禁止期間は長 くなり, vinylchloride の単独重台が始まってもその重合速度は遅い。

1. 緒

言

前報" において多量の酸素の存在下で塩化ビニル(VC と略記する)を乳化重合をせしめようとしても，VC

* 住友化学工密株式会社新居捠造所研究部（新居捠市乙 31） 